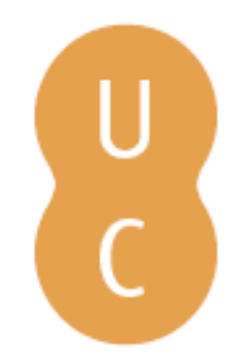

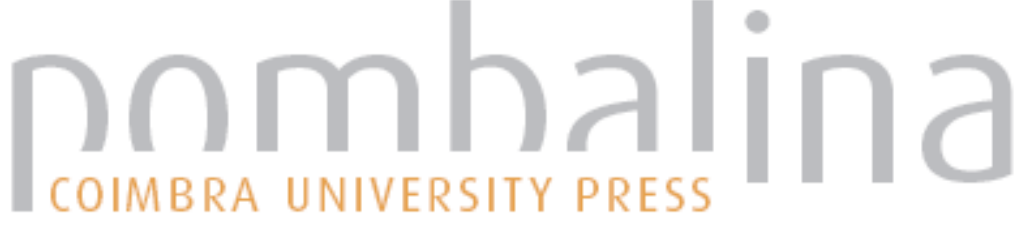

\section{A gentle and worldly woman}

Autor(es): Whitford, Bill

Publicado por: Imprensa da Universidade de Coimbra

URL

persistente: URI:http://hdl.handle.net/10316.2/42376

DOI: $\quad$ DOI:https://doi.org./10.14195/978-989-26-1308-6_59

Accessed : $\quad$ 26-Apr-2023 13:56:35

A navegação consulta e descarregamento dos títulos inseridos nas Bibliotecas Digitais UC Digitalis, UC Pombalina e UC Impactum, pressupõem a aceitação plena e sem reservas dos Termos e Condições de Uso destas Bibliotecas Digitais, disponíveis em https://digitalis.uc.pt/pt-pt/termos.

Conforme exposto nos referidos Termos e Condições de Uso, o descarregamento de títulos de acesso restrito requer uma licença válida de autorização devendo o utilizador aceder ao(s) documento(s) a partir de um endereço de IP da instituição detentora da supramencionada licença.

Ao utilizador é apenas permitido o descarregamento para uso pessoal, pelo que o emprego do(s) título(s) descarregado(s) para outro fim, designadamente comercial, carece de autorização do respetivo autor ou editor da obra.

Na medida em que todas as obras da UC Digitalis se encontram protegidas pelo Código do Direito de Autor e Direitos Conexos e demais legislação aplicável, toda a cópia, parcial ou total, deste documento, nos casos em que é legalmente admitida, deverá conter ou fazer-se acompanhar por este aviso. 



\section{A GENTLE AND WORLDLY WOMAN}

Bill Whitford

Professor Maria Irene Ramalho de Sousa Santos has been a close friend for many years, and for the past 25 years or so as a housemate during the months she and her husband are working at the University of Wisconsin-Madison. We have seen Irene (as we call her) hard at work and I have read several of her many academic papers. But I am not professionally competent to critique her professional work and will not attempt to do so, except to attest that she works hard at it and is very dedicated to it.

I will comment instead as a friend who knows Irene very well. One way to describe Irene is that she is "well raised". By that I mean far more than that she has good manners, though that is certainly true as well. Irene is somebody who has empathy, and who is attentive to the situations and moods of persons around her. She is always ready to lend a sympathetic ear when it is needed, and to offer suggestions as appropriate. And she is always willing to help when needed.

Irene is also a very worldly person, who has traveled to many places and studied many subjects. She is an interesting conversationalist about almost all topics, and especially those related to literature, her academic specialty. Irene is a committed feminist and a democratic socialist, passionate about matters that touch on these deep ideological commitments. 
No testimonial to Irene could neglect to mention how devoted she is to her family, and to the idea of family. She relishes her family relationships, whether they be as wife, mother or grandmother, and she devotes a great deal of her energy to nurturing them. And we believe that all of her family are better for it.

With Love, Bill 